\title{
Identification and Detection of a Virus Associated with Strawberry Pallidosis Disease
}

Ioannis E. Tzanetakis and Anne B. Halgren, Department of Botany and Plant Pathology, Oregon State University, Corvallis 97331; Karen E. Keller, Horticulture Crops Research Lab, USDA-ARS, Corvallis 97330; Stanley C. Hokanson, Department of Horticultural Science, University of Minnesota, St. Paul 55108; John L. Maas, USDAARS Fruit Lab, Beltsville 20705; Paul L. McCarthy and Robert R. Martin, Horticulture Crops Research Lab, USDA-ARS, Corvallis 97330

\begin{abstract}
Tzanetakis, I. E., Halgren, A. B., Keller, K. E., Hokanson, S. C., Maas, J. L., McCarthy, P. L., and Martin, R. R. 2004. Identification and detection of a virus associated with strawberry pallidosis disease. Plant Dis. 88:383-390.

The etiology of pallidosis, a disease of strawberry identified more than 45 years ago, remains unknown. We report a putative agent of the disease, a virus belonging to the Crinivirus genus of the Closterovirideae family. A sensitive reverse transcription-polymerase chain reaction (RTPCR) test has been developed. Polyclonal antibodies that can be used to detect the virus in petiole tissue blots were developed using a recombinant virus coat protein. The nucleotide sequences of regions of the viral genome that encode the heat shock protein 70 homolog and the major coat protein were obtained. Alignments of the major coat protein show that the virus isolated from strawberry plants positive for pallidosis is most closely related to Cucumber yellows virus (syn. Beet pseudo-yellows virus) and Cucurbit yellow stunt disorder virus, members of the Crinivirus genus.
\end{abstract}

Pallidosis is a disease of strawberry first reported in California and Australia in 1957 (6). Since then it has been reported in Eastern Canada (4), Arkansas (8), and Maryland (10). Pallidosis disease is an unrecognized or under-recognized problem in the strawberry industry, but there are recent studies showing that the disease is very widespread in the Mid-Atlantic states (10). In greenhouse-grown plants of 'Northwest' strawberry, the disease reduces runner production and root growth by 15 to $20 \%$ (3). However, its major impact in yield loss is believed to result when it occurs in mixed infections with other strawberry viruses (16).

The pallidosis agent is graft-transmitted, and high-molecular-weight dsRNA species have been purified previously from infected plants (21). Inclusion bodies similar to those of Beet yellows virus (BYV), the type member of the Closterovirideae family of plant viruses, have been observed in plants that indexed positive for pallidosis (9). Several lines of evidence suggest that the pallidosis disease is of viral etiology. Pallidosis is defined as a disease caused by

Corresponding author: Robert R. Martin

E-mail: martinrr@science.oregonstate.edu

Accepted for publication 12 December 2003

Publication no. D-2004-0203-01R

This article is in the public domain and not copyrightable. It may be freely reprinted with customary crediting of the source. The American Phytopathological Society, 2004. a graft transmissible agent(s) that causes distortion, chlorosis of leaves, and dwarfing of grafted Fragaria virginiana, 'UC10 ' or 'UC-11' plants, while $F$. vesca indicator plants and commercial strawberry cultivars remain symptomless. It is important to note that because of the latent infection in most cultivars, the detection of the disease has only been possible by grafting onto both $F$. virginiana and $F$. vesca indicator plants (7).

We report a putative causal agent of pallidosis disease, a virus in the Crinivirus genus of the Closterovirideae family, and tentatively designate it as Strawberry pallidosis associated virus (SPaV). In addition, the complete nucleotide sequences of the heat shock protein 70 homolog (HSP70h) and major coat protein (CP) genes of the virus are presented, and molecular and immunological assays developed for detection of SPaV are described.

\section{MATERIALS AND METHODS}

Plant source. Strawberry plants (Fragaria $\times$ ananassa) from commercial fields in Maryland were tested at the USDAARS Fruit Laboratory in Beltsville, MD, for virus infection by grafting onto indicator plants $F$. vesca ('UC-4' or 'UC-5') and $F$. virginiana ('UC-10' or ' $\mathrm{UC}-11$ ') as described previously (5). Source plants that resulted in symptoms when grafted onto $F$. virginiana plants (yellowing, distortion of leaves, cachexia) but failed to cause any visible symptoms on $F$. vesca plants were considered to have pallidosis. Twenty-nine individual strawberry plants from commercial fields in Maryland (M1 to M29), two from California (C1 and C2) that indexed positive for pallidosis by grafting at USDA-ARS, Corvallis, OR, seven pallidosis isolates from the National Clonal Germplasm Repository (NCGR) in Corvallis (CFRA no. 9006, 9037, 9038, 9064, 9065, 9067, 9087), and 12 certified virus-free plants from USDA-ARS, Corvallis, were used.

Mechanical transmission. Plants belonging to 24 species and eight families (Table 1) were mechanically inoculated with a mix of leaf tissue of the seven NCGR pallidosis isolates. Four plants of each species were inoculated twice. The $\mathrm{wt} / \mathrm{vol}$ ratio was $1: 10$ to $1: 20$ in phosphate buffered saline (PBS), pH 7.4, with the addition of $2 \%$ nicotine. Carborundum (600 mesh) was added on the leaf surface to facilitate delivery of the pallidosis agent(s) into the indicator plants.

Purification of virus and dsRNA. Virus was purified as described previously (14) with the initial wt/vol ratio changed to $1: 6$ or $1: 10$ due to the viscosity of the strawberry tissue. Double-stranded RNA

Table 1. Indicator plants used for mechanical transmission of Strawberry pallidosis associated virus

\begin{tabular}{ll}
\hline Plant name & Family \\
\hline Antirrhinum majus & Scrophulariaceae \\
Beta vulgaris & Chenopodiaceae \\
Chenopodium giganteum & Chenopodiaceae \\
Chenopodium quinoa & Chenopodiaceae \\
Cucumis sativus & Cucurbitaceae \\
Datura stramonium & Solanaceae \\
Glycine max & Fabaceae \\
Gomphrena globosa & Amaranthaceae \\
Lathyrus odoratus & Fabaceae \\
Lactuca sativa & Asteraceae \\
Lycopersicon esculentum & Solanaceae \\
Medicago sativa & Fabaceae \\
Nicotiana benthamiana & Solanaceae \\
Nicotiana glutinosa & Solanaceae \\
Nicotiana rustica & Solanaceae \\
Nicotiana tabacum & Solanaceae \\
(cv. Samsun NN) & \\
Petunia $\times$ hybrida & Solanaceae \\
Phaseolus vulgaris & Fabaceae \\
Phlox drummondii & Polemoniaceae \\
Pisum sativum & Fabaceae \\
Spinacia oleracea & Chenopodiaceae \\
Tagetes patula & Asteraceae \\
Trifolium pratense & Fabaceae \\
Vigna unguiculata & Fabaceae \\
\hline
\end{tabular}


(dsRNA) was purified as described previously (21) from 22 of the available pallidosis isolates in addition to four certified virus-free strawberry cultivar plants. At least 100 dsRNA extractions were carried out in this study and subjected to gel electrophoresis. After extraction, the dsRNA was aliquoted and precipitated by centrifugation at $16,000 \times \mathrm{g}$ for $30 \mathrm{~min}$ at room temperature in $70 \%$ ethanol and $0.1 \mathrm{M}$ sodium acetate. The dsRNA was resuspended in $10 \mu \mathrm{l}$ of Tris-borate-EDTA (TBE), pH 8.0, and was resolved by electrophoresis through a $1 \%$ agarose gel containing ethidium bromide at $100 \mathrm{ng} / \mathrm{ml}$.

Cloning and analysis. An amount of dsRNA equivalent to that extracted from 4 $\mathrm{g}$ of fresh strawberry leaf tissue of Maryland field isolate M1 was incubated with $20 \mathrm{mM}$ methyl mercuric hydroxide and random nucleotide hexamer primers $(0.5$ $\mu \mathrm{g}$ ) (Invitrogen, Carlsbad, CA) for $20 \mathrm{~min}$ at room temperature in water. The cDNA synthesis was performed according to the manufacturer's instructions using Thermoscript reverse transcriptase (RT) (Invitrogen) in a final volume of $50 \mu \mathrm{l}$. The cDNA was ethanol precipitated, air-dried, and second-strand synthesis carried out as described previously (12). The products were then adenylated at the $3^{\prime}$ ends using Taq polymerase (Invitrogen) (1 unit) added to the second-strand synthesis reaction and incubated for $15 \mathrm{~min}$ at $72^{\circ} \mathrm{C}$. The cDNA products then were purified utilizing the rapid polymerase chain reaction (PCR) purification system (Marligen Biosciences, Ijamsville, MD) prior to ligation. The products were concentrated to a volume of $4 \mu \mathrm{l}$ and cloned into the pCR2.1 TOPO vector (Invitrogen) according to the manufacturer's instructions. The recombinant plasmids were purified, digested with EcoRI (New England Biolabs, Beverly, MA), and analyzed using agarose gel electrophoresis. Several clones with inserts ranging from 600 to 2,500 nucleotides were sequenced in the Central Services
Laboratory at Oregon State University using an ABI 377 DNA sequencer. The BLAST databases (blastn and blastp) at the National Center for Biotechnology Information (NCBI, published online) were used to compare the unknown sequences to the GenBank's nucleotide and protein databases, respectively.

Three clones (SP 21, SP 37, and SP 44) corresponding to the HSP70h gene and two clones (SP 60 and SP 63) corresponding to the $\mathrm{CP}$ gene of the virus were identified after using BLAST by comparison with related sequences in the database. Oligonucleotide primers HSP 5', HSP 3', CP 5', and CP 3' (Table 2) were developed, which allowed the amplification of the complete HSP70h (HSP 5'/HSP $3^{\prime}$ ) and CP (CP 5'/CP 3') genes by RT-PCR. The firststrand cDNA was prepared using reverse transcriptase as described above from dsRNA, and $5 \mu \mathrm{l}$ of the RT reaction was used as template in a 50- $\mu$ PCR reaction that consisted of $50 \mathrm{mM} \mathrm{KCl}, 10 \mathrm{mM}$ Tris$\mathrm{HCl}$ (pH 9.0), 0.1\% Triton X-100, 2 mM $\mathrm{MgCl}_{2}, 0.2 \mathrm{mM}$ dNTPs, $400 \mathrm{nM}$ each of 5' and $3^{\prime}$ primers, and 1 unit Taq Polymerase (Invitrogen).

The PCR program we used consisted of a 5-min denaturation step at $94^{\circ} \mathrm{C}$ followed by 40 cycles of $30 \mathrm{~s}$ denaturation at $94^{\circ} \mathrm{C}$, $30 \mathrm{~s}$ annealing at $50^{\circ} \mathrm{C}$, and $2.5 \mathrm{~min}$ extension at $72^{\circ} \mathrm{C}$, followed by a final extension time of $15 \mathrm{~min}$ at $72^{\circ} \mathrm{C}$. For DNA sequencing purposes, we used primers SP 37, SP 44F, and CP R (Table 2). We used isolates $\mathrm{M} 1$ and $\mathrm{C} 1$, a Maryland and a California field isolate, respectively, and CFRA 9064 from the NCGR, one of the N. W. Frazier clones in which the virus was first identified. The consensus of the sequences of both genes was constructed after sequencing two individual PCR reactions at least twice in both directions. However, for the HSP70h gene of isolate CFRA 9064, a PCR product was cloned into the pCR2.1 TOPO vector (Invitrogen), and three individual clones were sequenced twice using

Table 2. Oligonucleotide primers used for detection by reverse transcription-polymerase chain reaction, sequencing, and coat protein expression ${ }^{\mathrm{a}}$

\begin{tabular}{ll}
\hline Primer name & Nucleotide sequence $\left(\mathbf{5}^{\prime} \mathbf{- 3}^{\prime} \mathbf{)}\right.$ \\
\hline Detection primers & \\
SP 44F & GTGTCCAGTTATGCTAGTC \\
SP 44R & TAGCTGACTCATCAATAGTG \\
CP 5' & AGCTAGAACAAGGCAAGTC \\
CP $731 \mathrm{R}$ & GCCAATTGACTGACATTGAAG \\
SPL F & TGCTAATGATGGAGACCTCG \\
SPL R & GGTGTCTAACTTGTCGTTCC \\
CP modification and sequencing primers & \\
CP exp. F & ACGCACAGTCATATGGCTGAAACAACCG \\
CP exp. R & GAGCTACTCGAGGTTTCCGCCAATTGA \\
HSP 5' & GAGTCCGCTCTCCATGTGTT \\
HSP & AACGATCGGAATCAACTCTC \\
CP 5' & CAGCTAGAACAAGGCAAGTC \\
CP & TGGAACAGTGAGCTTGTCAG \\
SP 37 & AGCGTTGGGTCGGTGTTGAT \\
CP R & CAACGGATTATTCACGCCAG \\
\hline
\end{tabular}

${ }^{\mathrm{a}}$ For primers $\mathrm{CP}$ exp. F and CP exp. R, underlined sequence shows the NdeI and XhoI restriction sites, respectively, while bold indicates $\mathrm{CP}$ sequence. the primers mentioned above as well as the M13 forward and reverse primers. All consensus sequences were assembled using the Clustal W program (European Bioinformatics Institute, published online).

Detection by RT-PCR. RNA was extracted from $100 \mathrm{mg}$ of strawberry leaf tissue as described previously (11) and was resuspended in $40 \mu \mathrm{l}$ of water. Reverse transcription was performed using Superscript II reverse transcriptase (Invitrogen) according to the manufacturer's instructions using RNA as $1 / 10$ of the volume of the reaction and using $0.3 \mu \mathrm{g}$ of random nucleotide hexamers (Invitrogen). The reaction was terminated by heating at $75^{\circ} \mathrm{C}$ for $20 \mathrm{~min}$ followed by incubation with one unit of RNase H (Invitrogen) for 30 $\min$ at $37^{\circ} \mathrm{C}$. For PCR, we used primers SP $44 \mathrm{~F}$ and SP 44R that amplify a 517 base pair (bp) fragment of the HSP70h gene and CP $5^{\prime}$ and CP n731R (Table 2) that amplify a 752 bp fragment containing the largest part of the CP gene. We developed primers SPL F and SPL R (Table 2) that amplify a $301 \mathrm{bp}$ fragment of the strawberry pectate lyase B gene, which we used as an internal control in our PCR reactions. The program consisted of initial denaturation for $5 \mathrm{~min}$ at $94^{\circ} \mathrm{C}$ followed by 40 cycles with denaturation for $30 \mathrm{~s}$ at $94^{\circ} \mathrm{C}$, annealing for $30 \mathrm{~s}$ at $50^{\circ} \mathrm{C}$ for the $\mathrm{CP}$ primers or $55^{\circ} \mathrm{C}$ for the HSP70h primers, and extension for $1 \mathrm{~min}$ at $72^{\circ} \mathrm{C}$. The PCR reaction was essentially the same as described above with the addition of acetamide to a final concentration of $5 \%$ (1). To verify the amplification of the viral genes, several of the PCR products were sequenced, and the sequences showed greater than $99 \%$ sequence identity to the M1 isolate.

CP expression. Primers were developed for the cloning of the $\mathrm{CP}$ gene into the pET $21 \mathrm{~b}$ expression vector (Novagen, Madison WI). Primer CP exp. F introduces an NdeI restriction site at the $5^{\prime}$ end of the CP ORF, while primer CP exp. R (Table 2) introduces an XhoI site at the $3^{\prime}$ end of gene just prior to the stop codon. Singlestranded RNA extracted as described above from leaf tissue of field isolate M1 served as template for the RT reaction, and the PCR protocol consisted of one cycle of 5 min at $94^{\circ} \mathrm{C}, 1 \mathrm{~min}$ at $37^{\circ} \mathrm{C}$, and $1 \mathrm{~min}$ at $72^{\circ} \mathrm{C}$ followed by 35 cycles of $30 \mathrm{~s}$ at $94^{\circ} \mathrm{C}, 2 \mathrm{~min}$ at $72^{\circ} \mathrm{C}$, followed by final extension time of $15 \mathrm{~min}$ at $72^{\circ} \mathrm{C}$. The PCR product was purified utilizing the rapid PCR purification system (Marlingen Biosciences) according to the manufacturer's instructions and incubated overnight with 100 units of NdeI and XhoI (New England Biolabs, Beverly, MA). The same digestion reaction was performed with $1 \mu \mathrm{g}$ of pET $21 \mathrm{~b}$ plasmid (Novagen). The digested plasmid and PCR product were gel purified using the RNAaid kit (Bio 101, Carlsbad, CA) according to manufacturer's instructions. The ligation was performed using T4 DNA ligase (New 
England Biolabs) according to the manufacturer's instructions. Transcription of the gene was controlled by the T7 promoter, and the recombinant protein contained six histidine residues at the $\mathrm{C}$ terminus that were used for column purification. The final plasmid was transformed into $E$. coli (Epicurian Coli BL 21-CodonPlus cell line [Stratagene, La Jolla, CA]). A single colony was selected, and the presence of the plasmid was verified after amplification of the insert using the PCR protocol described above with primers M13 forward and reverse. The construct was sequenced three times using primers M13 forward and reverse as well as primer CP R to confirm that the insert was in frame, and expression of the protein was performed according to the manufacturer's instructions. One hundred microliters of cell suspension was sonicated and subjected to electrophoresis through $12 \%$ sodium dodecyl sulfate-polyacrylamide gel (SDSPAGE) followed by staining with Coomassie Brilliant Blue and Western blotting immunoassay according to standard procedures (17), using monoclonal anti-histidine and goat anti-mouse antibodies conjugated with alkaline phosphatase for detection according to manufacturer's
1

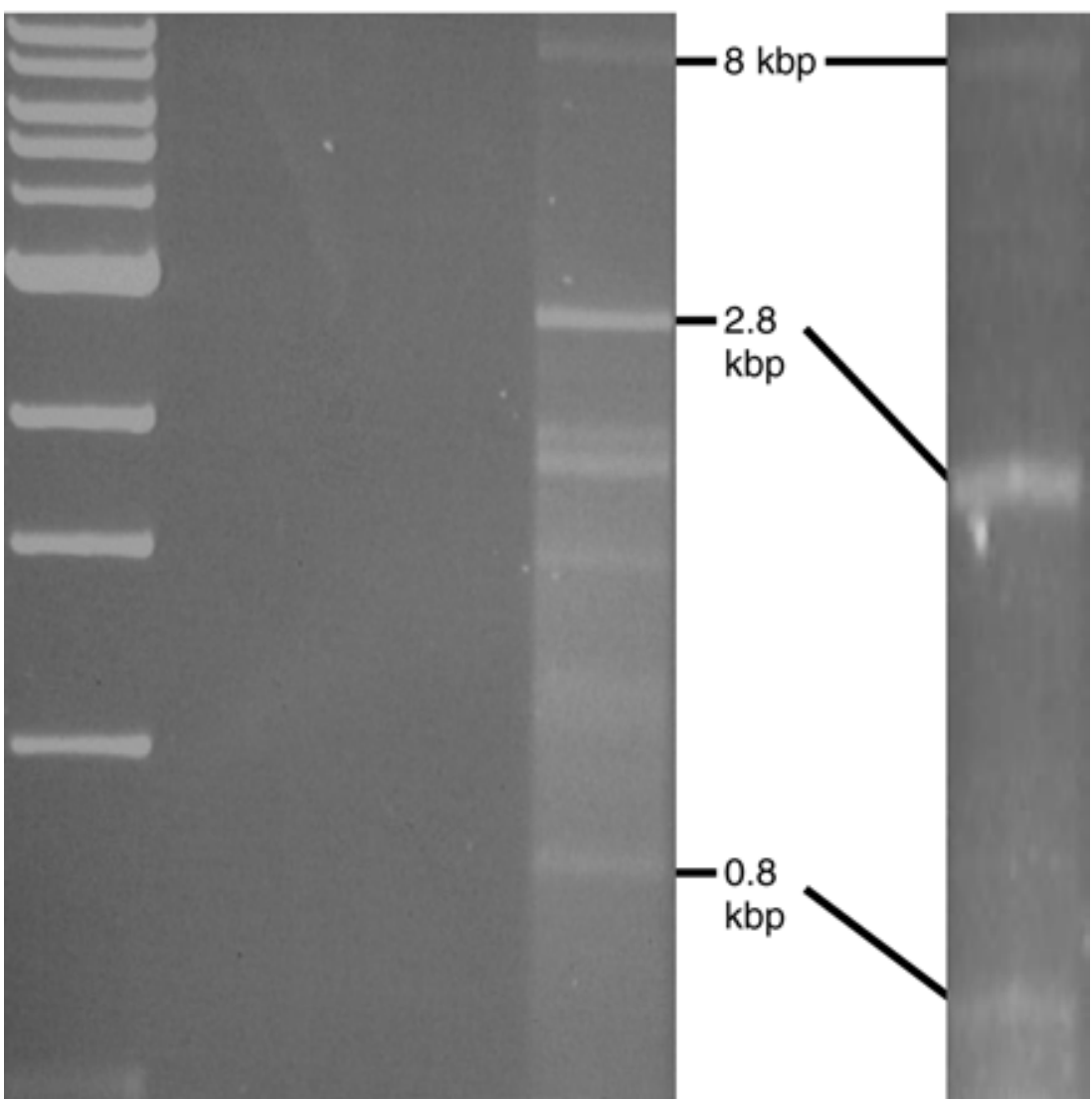

Fig. 1. DsRNA extracted from strawberry plants infected with the pallidosis agent. Lane 1: $1 \mathrm{kbp}$ DNA marker (BRL, Gaithersburg, MD); lane 2: blank; lane 3: dsRNA extracted from healthy strawberry plant; lane 4: dsRNA extracted from Strawberry pallidosis associated virus (SPaV)-infected plant in March; lane 5: dsRNA extracted from SPaV-infected plant in August. Arrows show the 8.5, 2.8 , and $0.9 \mathrm{kbp}$ bands present in all pallidosis isolate-infected tissue regardless of time of year. instructions (Sigma Chemicals, St. Louis, MO).

Following verification of the expressed protein by detection of the six histidine epitope in whole cell extracts, the protein was purified using Talon Metal Affinity Resins, utilizing the native buffer extraction method, and the Talon CellThru columns (both from Clontech, Palo Alto, CA). The purified protein was subjected to SDSPAGE and Western blotting. A New Zealand white rabbit was immunized by intramuscular injection with $200 \mu \mathrm{g}$ of the recombinant protein in Freund's complete adjuvant followed by a booster injection after a 2-week period. The final bleed was performed 2 weeks after the booster injection. purified from the rabbit antiserum using sodium sulfate precipitation, diluted to a concentration of $1 \mathrm{mg} / \mathrm{ml}$ in PBS and conjugated with alkaline phosphatase (Sigma) as described (2). Double antibody sandwich enzyme-linked immunosorbent assay (DAS-ELISA) was carried out as described previously (2). Leaf and petiole tissues were tested in ELISA at dilutions of 1:10 (wt/vol) in PBS containing $0.05 \%$ Tween 20, 2\% PVP-10,000, and $0.2 \%$ nonfat skim milk powder. Positive samples included a

4

5
Immunoassays. Immunoglobulins were cocktail of leaf or petiole sap of the two pallidosis isolates from the NCGR described above. A threshold of two times the average $A_{405}$ readings from healthy tissue was used. Antibody coating and conjugate concentrations ranging from 0.5 to 10 $\mu \mathrm{g} / \mathrm{ml}$ in all combinations were used to test the antiserum in ELISA. Each of these tests was done twice. For tissue blots, cross sections of petioles were blotted to 0.45 $\mu \mathrm{m}$ nitrocellulose membrane (Biorad, Hercules, CA) that was then washed twice with PBS-Tween and blocked by soaking in PBS-Tween containing 3\% nonfat skim milk powder for $1 \mathrm{~h}$. After a single wash with PBS-Tween, the membranes were transferred to antisera solutions (1:1,000 to $1: 25,000)$ diluted in PBS and incubated at room temperature for $1 \mathrm{~h}$. The filters were then washed three times in PBS-Tween and goat anti-rabbit alkaline phosphatase conjugate (Sigma) diluted 1:2,000 in PBS containing 2\% PVP-10,000, and $0.2 \%$ nonfat milk powder was added and the filters incubated for $1 \mathrm{~h}$ at room temperature. After washing as above, the filters were placed in buffer consisting of $0.1 \mathrm{M}$ Tris, $\mathrm{pH} 9.5,0.1 \mathrm{M} \mathrm{NaCl}$, and $5 \mathrm{mM}$ $\mathrm{MgCl}_{2}$, containing precipitating substrate (NBT/BCIP, Sigma). Reactions were stopped by transferring the filters to deionized water (18).

\section{RESULTS}

Mechanical transmissions. None of the 24 indicator plant species developed visible symptoms when mechanically inoculated with SPaV-infected tissue. Some plants had symptoms that were attributed to nicotine toxicity after testing the plants for the presence of SPaV by RT-PCR and inoculation of the plants with PBS without nicotine. We also tested one plant per treatment per species with RT-PCR for the presence of SPaV using the HSP70h primers without being able to acquire any amplicons.

Purification of virus and dsRNA. The virus purification gave low numbers of virions. The virions were 10 to $11 \mathrm{~nm}$ in diameter and ranged in length from 250 to $450 \mathrm{~nm}$ in length (data not shown), an indication that they were unstable and broke during purification. It was determined that the rods belonged to the virus by performing RT-PCR on fractions that contained rods in the electron microscope and on fractions where rods were absent. Amplicons were only generated in the fractions that contained rods.

Twenty-two of the 38 isolates were tested for presence of dsRNA. All 22 gave similar band patterns, while all healthy plant material gave either low molecular weight $(<200 \mathrm{bp})$ or no visible dsRNA bands (Fig. 1). All isolates had three predominant bands at $\sim 8.0,2.8$, and $0.8 \mathrm{kbp}$ (Fig. 1) with the exception of isolate M29, which has been verified to be Beet pseudoyellows virus (BPYV) (19) and not $\mathrm{SPaV}$ 
A

SPaV MTEAKVGLDFGTTFSTISSY INNKMHVLKINDSPYIPTCLAISIDKDVIIGGAAQVLDSS 60

CUYV -MQAKVGLDFGTTFSTISSFTNGEMKTLYVNNSPYIPTCLSISSEGDVIIGSAAQVIDES 59

CYSDV --MAKAGLDFGTTFSTISSYVNGVMKVLKLNETEFIPTCLAITSNNDVVVGGPAQVLSNS 58

SPCSV -MEAKAGLDFGTTFSTISAYVGGTMKVLRINGSEFIPTCLSVTATGDVVVGGAAQVLDSS 59

TOCV -MSIKAGLDFGTTFSTISCFYNNKLFSLKLNGTEYIPTCLSITPNNEVIVGGPSQVLEAS 59

LIYV MRDCKVGLDFGTTFSTVSTLVNNSMYVLRLGDSAYIPTCIAITPGGEAIIGGAAEVLSGD 60

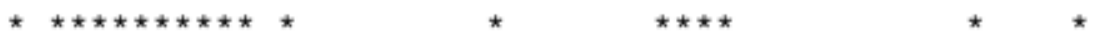

SPAV EVANCYFYDLKRWVGVDKVNFENIKAKINPQYVAKLVNDDVMLTGVDRGYSCTYTVKQLI 120

CUYV EVKSCYFYDLKRWVGVDATNFLVIKEKIKPLYVVKLVGNDVYYTGVNKGFSCTYTVKQLI 119

CYSDV DMPNCYFYDLKRWVGVDSINYNVIKTKINPVYVTELRGNDVYITGIDRGYTCTYTVKQLI 118

SPCSV QLPHCYFYDLKRWVGVDRLSFEEIKRKISPQYTVRLEGNDVLITGISKGFSCTYTVKQLI 119

TOCV ETPSCYFYDLKRWVGVTSVNYEVVKAKINPTYKTRLSNNKVYITGINKGFSTEFSVEQLI 119

LIYV DTPHCFFYDLKRWVGVDDNTFKFAMNKIRPKYVAELVEGEVYLTGINKGFSI KLSVKQLI 120

$\star \star \star \star \star * \star * \star * \star * *$

$\star \star * \star * \quad * \quad * * \quad * \quad * \star * *$

SPAV LLYIDTLVRLFSKTDNLNI ISLNVSVPADYKCKQRMFMKSVCDSLNFSLRRI INEPSAAA 180

CUYV LLFIDTMVRLFSKTNNLNI I SLNVSVPADYKCKQRMFMKSVCDSLNFSLRRI INEPSAAA 179

CYSDV LLYIETLVRLFSKVESITITSLNVSVPADYKCKQRMFMKSVCDSLGFSLRRI INEPSAAA 178

SPCSV LLYVDTLVRLFSNVEKLKILSLNVSVPADYKTKQRMFMKSVCESLGFPLRRI INEPSAAA 179

TOCV LHYVNTLVRLFSKTENLKITDLNVSVPADYKSGQRLFMQAVCSSLGFNLRRIVNEPSAAA 179

LIYV KAYIETIVRLLASSYSLRVIDLNQSVPADYKNAQRLAARSVLKALSFPCRRI INEPSAAA 180

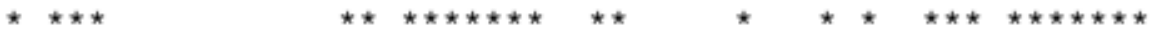

SPAV IYSVSKYPNYKYFLMYDFGGGTFDTSLIVRDGKVVTVADTEGDSFLGGRDIDNAISRFIV 240

CUYV IYSVSKYPQHNYFIMYDFGGGTFDTSLITRDGQYVTVADTEGDSFLGGRDIDNEIQQFIV 239

CYSDV IYFVSKYPQYNNFLMYDFGGGTFDSSLIVRDGKYVTVADTEGDSFLGGRDIDNAIADYIT 238

SPCSV IYSISKHPGFDYFLVYDFGGGTFDTSLIAKDGKFVTVADTLGDSFLGGRDIDRAILSHIM 239

TOCV IYCVSKYPQYAYFYIYDFGGGTFDTSLIVRYGKFVTVADTQGDSFLGGRDIDKTISKFIM 239

LIYV VYCVSRYPNYNYFLVYDFGGGTFDVSLIGKYKSYVTVIDTEGDSFLGGRDIDKSIEDYLV 240

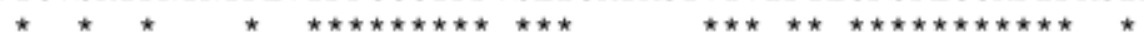

SPAV EKHSLPRPLSSDFLASIKEEVNNSSKSNFIALDTKGNIVNVSFNKDDLATCIQPFSVKSI 300 CUYV KSNNLSRPLPSDFLASIKEDCNTTGKSTFNVMDVDGKLLTIRFSREDLAACIEPYSKRSL 299 CYSDV TTYGMKGGLSADVLASIKEDCNSKGRENFNVIDSSGKLHNVKFTRQDLSRCIEPFSKKSI 298 SPCSV RTNSLQKPLSADSLA.AIKEEVNSTGRSNFNVLDVDGNI IFVNFSGEELDKIVSKFTAKSL 299 TOCV DKNALNAPLSADMLASI KEETNSTGRSSYNI I SDDGS I INIQFTFDDLVKCVEPFARRSF 299 LIYV GKYNIKKVIPATYLALIKEECNNTNKSIFTILFDDGSVQVVEFSKSELEKCVRPFVERSI 300

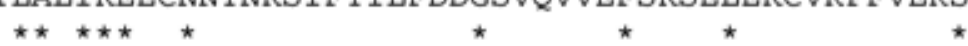

SPaV KILDNLVGRRKITNGALFLVGGSSLLKKIQQDVSSYARSKGLTCVIDEDLRCSVSFGCSM 360

CUYV KILDNLVKRRKISSGALFLVGGSSLLSKVQQDVAAYASANNFECVIDKDLRCSVSFGCSM 359

CYSDV ALLDNMVVRNITKDSAVFMVGGSSLLKKVQHDVMNYCARTKLECI IDKDLRSAVSFGCSM 358

SPCSV KILKAIADRNKITSGALFLVGGSSLLRKVQLDVSNFAKSIGLTPIIDKDLRSAVSYGCSM 359

TOCV SILRSLVSRNKTSNGALFLVGGSSLLRPIQNRADGFARNHGLALI IDPDLRAAVSFGCSM 359

LIYV KLINDVVVRNKLTSGVIYMVGGSSLLQPVQDMVRSYASTKGLTLVADQDMRSAVSYGCSV 360

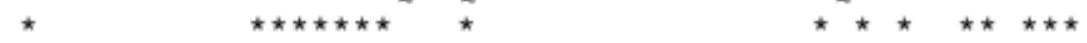

SPAV QHAQEDSGSMTYIDCNSHPLMDLLMYGNPKVVVRKPMPIPYTKYDTRTIRQHYNTVVNVY 420 CUYV QHAQEDSGSMIYIDCNSHPLMDLTLFGNPKVVVRKPMSIPYSTSDSRTIRSHYSTAVNVY 419

CYSDV SHAQEDTKNMIYIDCNSHPLMDISYFCSPKIIVRKPMAIPYTGVREETLTRHYTTILNVY 418

SPCSV MHAQEDSGSMVYIDCNSHPLMDVSLFANPRVIIRKPMSVPFSYKTTRKVDRHMMTAVNVY 419

TOCV LHAQEDSGNMTYIDCNSHPLMDLGLYCHPRI I IRKPMSVPYTHKIEREVTRFITTALNVY 419

LIYV LHKLEDNKEIVYIDCNSHPLSDISFNCDPEPI IRKPMSIPYTHTVKMRHDRPLKTIVNIY 420

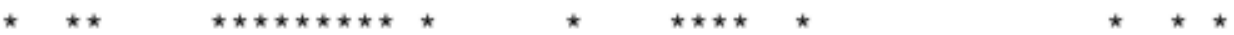

(continued on next page)

Fig. 2. A, Amino acids alignment of the heat shock protein 70 homolog (HSP70h) of Strawberry pallidosis associated virus (SPaV, accession no. AAO 92347), Cucumber yellows virus (CuYV, accession no. NP 821143), Cucurbit yellow stunt disorder virus (CYSDV, accession no. NP 851572), Sweet potato chlorotic stunting virus (SPCSV, accession no. NP 689401), Tomato chlorosis virus (ToCV, accession no. AAD 01790) and Lettuce infectious yellows virus (accession no. NP 619695). B, Amino acids alignment of the coat protein of SPaV (accession no. AAO 92342), CuYV (accession no. NP 821146), and CYSDV (accession no. NP 851576). Asterisks indicate identical amino acids in aligned proteins. 
infected. Additional bands were observed ranging in size from 4 to $\sim 1.3 \mathrm{kbp}$, but the intensity of these bands varied, depending on the season.

Cloning and analysis. Preparation of cDNA from isolate M1 using random hexamer nucleotide primers and cloning as described above resulted in the production of multiple clones for analysis. BLAST searches showed that the putative pallido- sis virus had sequence similarity to $\mathrm{Cu}$ cumber yellows virus (CuYV), a strain of BPYV, Cucurbit yellow stunt disorder virus (CYSDV) (Fig. 2), Sweet potato chlorotic stunting virus, and Lettuce infectious yellows virus, the type member of the Crinivirus genus. The search indicated that sequences that flanked the HSP70h and the $\mathrm{CP}$ genes of the virus were present in the clones. Primers developed to these flank- ing regions allowed the amplification by RT-PCR of the complete HSP70h and CP sequences of the unknown virus. The GenBank accession numbers are AY 262158 to AY 262160 for the CP genes and AY 262161 to AY 262163 for the HSP70h genes of M1, CFRA 9064, and C1 isolates, respectively.

Detection by RT-PCR. SPaV was detected in 37 out of the 38 isolates of pal-

\begin{abstract}
A (continued)
SPAV KKLYSALCDVNKNFNN 556

CUYV KELLERLVKQNKNFS - 554

CYSDV EDLYKSLAALNKNFK- 553

SPCSV RSLYERLIFVNKNFS- 554

TOCV KGLYNRLVEQNRNFS- 554

LIYV KTLYRRLKSMNANF- - 554

* * * **
\end{abstract}

SPAV EGSDLFVLNNDWLVSAKVNTSDHANVGEDLTFVYKYTIDGILELYAKNEKTGVEKLLPNT 480 CUYV EGSDIFTLNNDWLISANVRTSDHVNVGEDLVFIYKYNIDGILELYAKNGRTGVEKLLPNS 479

CYSDV EGSDPFVLNNDWLISANMQSNKYGEIGDTLQYLYKYNVDGILELVVRNKRTGKETVLPNS 478

SPCSV EGSSLFVLDNDWLVSANVNTQDFVDLGQELSYVYKYNVDGILDLFVRNESTGVESLLPNS 479

TOCV EGSDLFVLNNDWLISADVDYSKYAKMGETLVSVYKYTIDGILELSMANKTTGKSWVLPNT 479

LIYV EGSNLFMPENDWLISSNINTTDFAKVGEEYSKVYEYDIDGIITLKIRNEVTGKMFTLPNS 480

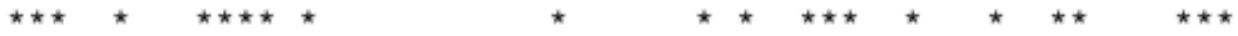

SPAV FSLTEKINKLDLQLTQLSTIDESATLISIMSYFDDNYTRLLSLLRTPTILERELLKITST 540

CUYV FSLTEKIEKLNLKLTQLSNVDEIATILSILSAFDDSLTGLLKFVKTPSILEREVAKISTP 539

CYSDV FALTESIKKLDVNLTQLSNIDELATLVAIMSYYKPELKYLLTYVKTPTIFENEIKKFGSG 538

SPCSV FALTEKVKKLDLNLTQLSSVDELATVVSILSHFDSSFSSLLKLVNTPSIFETSAAKFGDL 539

TOCV FARSEKIVISDLTLTQLSNVDELATIVSILSYFDTTFNYLISMFNTPSIFEREVGKISDA 539

LIYV FTKSDNIKPITFKLTQLSNTDDLATLTSLLGYHDKNFERFYGLFNVPTILIKEIDKLGGF 540

* $\quad * \star * * * * * * \quad * *$ *

B

SPaV MAETTG-----DAPVINAETAPPRDQEVRNRSNEEFDEGFFSRAFNSVSKRDDVANDSH 54

CUYV MGDNDDGKKSDDNVQLQNDVPAPVENKILDQKKLDEFSK - - IDRMISSLGRRDDIVNQDI 58

CYSDV MASSSENKTSKDDTKIISEHVEDESDNETKGVTKKDIDG----DNKSTYNPRD-LITADH 55

*

SPAV SDPNTFSDIKVTADRGDTLNEEQNKKYEVKLKEYCQTITKVDVDEKTFLAFYCSLIKMAK 114

CUYV LEADVLKSIDVTADRGDVLNTQDSETFVRLCKSFCKSVVKAEVNEKQFTGFYLSFIQAAL 118

CYSDV MDPTKLKDIKVFSNRADVMSDQDEATFAKCMKDFATIVFGKEPDEKEFLTFYISLVQCWL 115

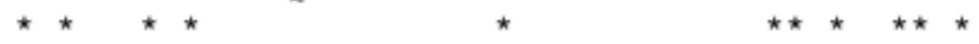

SPAV NQSTSIRNNNNPHLTNSFSVADKTFSYKTKDFLTFMAPHFTGVNNPLRRYMRKNEGRIKT 174

CUYV NQSTSTKNLRNENLINTFKVDDQTYSWKTAHFIRFIKGHFPTIDNPIRQYLRGNENQVAI 178

CYSDV NQSTSMKNAKQMNLTNTLMHGDQKKTWRTADFINYVKGNLPHVPNPFRQYARAHEHEIEI 175

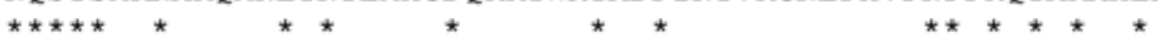

SPAV ISAAAGIDSDGHLAAKHGTTSQFWGATSDFTNGCETNISDDDLAANYMQREAATKNKARS 234

CUYV LRATGKLKSDGHLAAKHGTTTQFWDSTSDFTNGCKVNISDDDLTANWLQRETATKGKNKK 238

CYSDV LKATGKVTVDHHLQAKHGVLPQFWNVPADYVNGSLMNISEDDLAANLLMKCQALKRNEKE 235

*
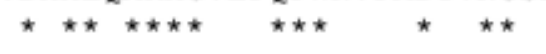

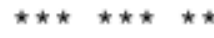

* *

SPAV RTIFNVSQLAGNVQ-- 248

CUYV NTIYNVSQLASYGN-- 252

CYSDV KKYYNVSQLAPGGCGN 251

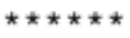

Fig. 2. (continued from previous page) 
lidosis used in this study, and none of the 12 healthy plants gave any pallidosisspecific amplicons, while PCR with the pectate lyase primers did result in 301-bp amplicons (Fig. 3). Several additional sets of primers specific for parts of the HSP70h and $\mathrm{CP}$ genes of the $\mathrm{SPaV}$ genome were tested, and all failed to amplify any regions using ds- or ssRNA from isolate M29.

Major CP expression and immunoassays. Using the antibodies to $\mathrm{SPaV}$, the virus was detected in petiole tissue blots (Fig. 4) from greenhouse material during the late autumn, winter, and spring months but not during the summer and early autumn. The ELISA was not sensitive enough to detect the virus at any time of the year, probably because of the low titer of the virus. Absorbance values in ELISA ranged from 0.1 to 0.2 depending on con- centration of coating and conjugated antibodies with no separation between infected and healthy tissue. The tissue blot immunoassay is more sensitive than the ELISA procedure for $\mathrm{SPaV}$ detection in plants, and we were able to visualize the localization of the virus in the vascular tissue of infected plants (Fig. 4).

Judging from the dsRNA band intensity after gel electrophoresis (Fig. 1), the intensity of the bands of PCR products from the RT-PCR test, and the tissue blot results (data not shown), we believe that the virus reaches its maximum titer in late winter under greenhouse conditions and its lowest titer during the late summer months and the beginning of fall. Lane 5 in Figure 1 represents the best dsRNA extraction obtained in late summer; generally no dsRNA was visible in gels at that time of the year.

A

1

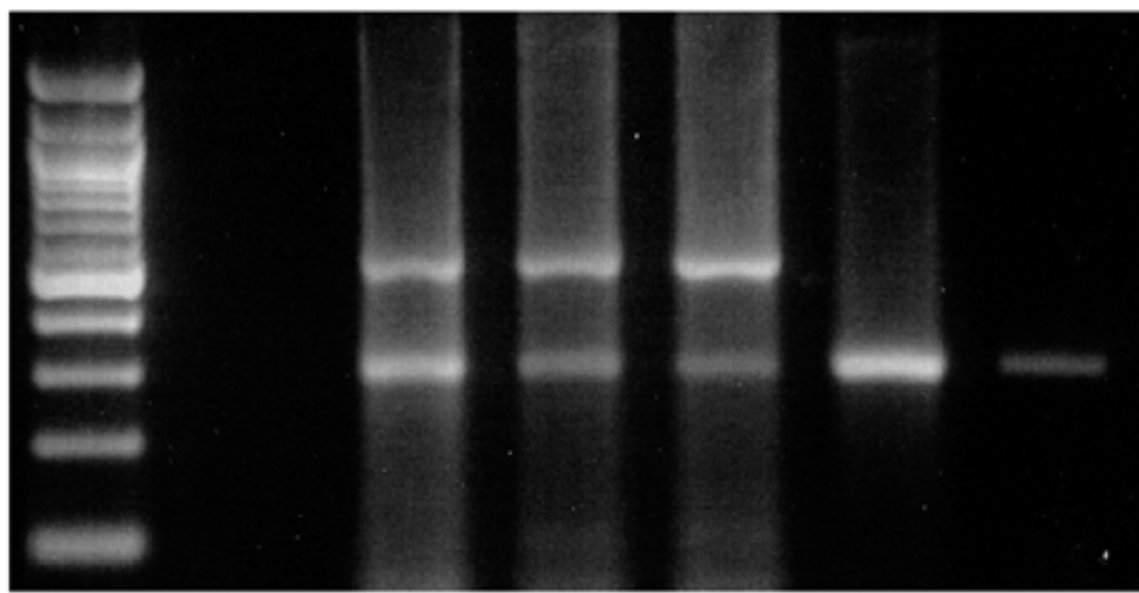

B

1

2

3

4

5

6

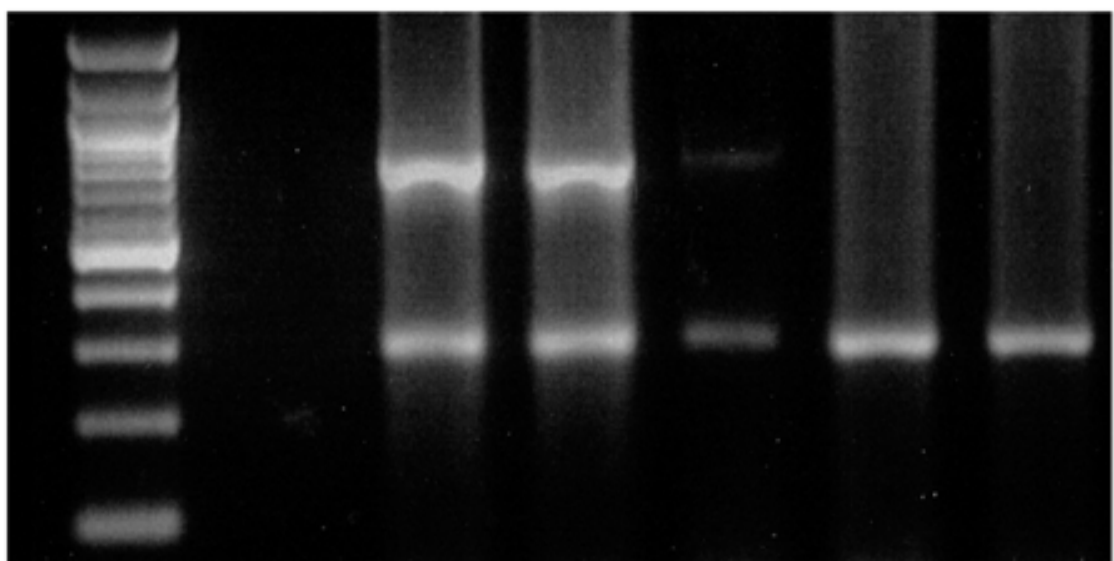

Fig. 3. Reverse transcription-polymerase chain reaction (RT-PCR) detection of Strawberry pallidosis associated virus $(\mathrm{SPaV})$. Ethidium bromide stained agarose gel with RT-PCR products of heat shock protein 70 homolog (A) and coat protein (B). Lane 1: 100 bp DNA ladder (BRL, Gaithersburg, MD); lanes 3 to 5: SPaV isolates M1, M2, and CFRA 9037, respectively; lane 6: Isolate M29, Beet pseudoyellows virus infected plant; lanes 7: healthy control; lane 2 is blank. The top band in both cases is an amplicon of the virus genome while the bottom band is an amplicon of the strawberry pectate lyase B gene used as an internal control.
This fact makes greenhouse detection of SPaV extremely difficult during the summer and early fall using the tissue blot technique.

\section{DISCUSSION}

By definition, strawberry pallidosis is a disease caused by a graft-transmissible agent(s) that induces visible symptoms in F. virginiana ('UC-10' or 'UC-11') but not in $F$. vesca indicators (7). It is common to get false negatives in graft assays since symptom development requires exact environmental conditions (R. R. Martin, personal observation). Strawberry pallidosis disease is common in strawberry plantings of all ages in the Mid-Atlantic states (10), while the disease appears to spread slowly in eastern Canada but more rapidly in the southern United States (7). Inclusion bodies similar to those produced by BYV, the type member of the Closterovirideae, have been reported in strawberries infected with pallidosis disease (9).

In the present study, we have identified $\mathrm{SPaV}$ as the putative causal agent of strawberry pallidosis. The virus belongs to the Closterovirideae family since it encodes the trademark gene of closteroviruses, the HSP70h gene. The alignment of the HSP70h and CP genes of SPaV shows multiple conserved residues with other viruses belonging to the Crinivirus genus (Fig. 2). The HSP70h shares over 34\% amino acid identity with all fully sequenced crinivirus HSP70h genes found in the database (Fig. 2A), while the CP has $43 \%$ amino acid identity with CuYV (BPYV) and $31 \%$ with CYSDV (Fig. 2B). The expectation (E) value is less than $\mathrm{e}^{-160}$ for the HSP70h gene and less than $\mathrm{e}^{-31}$ for the CP genes of CuYV and CYSDV. The two field isolates used for sequencing analysis originated from California (C1) and Maryland (M1), indicating some homogeneity in the virus populations since there are minimal differences between them, while the NCGR isolate (CFRA 9064) shows some diversity in the HSP70h gene. Unfortunately, we cannot draw more conclusions about the variability in the NCGR isolate because it has been maintained in a strawberry clone that has been propagated for more than 30 years, increasing the potential for accumulation of hypervariable genes (15).

A method for the detection of SPaV by RT-PCR was developed that allowed successful detection of the virus in 37 of the 38 isolates of strawberry pallidosis used in this study, while in the last isolate BPYV was present (19). Strawberry has been an extremely difficult host for RNA extractions, and the procedure described here is the only one that has been reliable, although the yield of the ssRNA may not be optimal. Using RT-PCR with the detection primers listed, a laboratory test is feasible for a virus that was previously only detected by grafting onto two different indi- 
cator plants. The detection by RT-PCR will benefit growers, since it is believed that the virus is primarily introduced to the field from strawberry nurseries. In a survey in Maryland, the number of strawberry plants with pallidosis was independent of how long the plants had been in the field, with infection rates approximately $70 \%$ (10). The RT-PCR protocol was used to test 50 strawberry samples from southern California, and $78 \%$ of these samples tested positive for $\mathrm{SPaV}$ (I. E. Tzanetakis, unpublished data). In California, infection may occur in the field, since whiteflies are common in the strawberry plants there and whiteflies are the only known vector of criniviruses, although contamination of the nursery stock cannot be ruled out. It is also likely that since $\mathrm{SPaV}$ is most probably whitefly-vectored, field spread will be more of a problem in warmer regions where whiteflies are established in the field than in the cooler regions where whiteflies are less common. Testing of nursery and field plants will be required to determine the amount of virus in planting stock and the rate of spread of SPaV in the field.

Attempts to purify $\mathrm{SPaV}$ from strawberry gave very low virus yields, and hence we expressed the recombinant $\mathrm{CP}$ gene in E. coli. The expressed protein was used to develop antibodies that allowed detection of the virus with tissue blot immunoassays in the vascular tissue of the plants as expected with viruses in the Closterovirideae family $(13,20)$. This detection procedure is season-dependent because of the low titer of the virus in strawberry during summer months. Based on the tis- sue blots and the samples used for dsRNA analysis in this study, it appears that detection of $\mathrm{SPaV}$ may be season dependent, an effect not previously reported.

The detection of $\mathrm{SPaV}$ by tissue blots but not by ELISA even during optimal times for testing suggests that the antibodies produced to the expressed protein may not recognize intact virus or that ELISA is not as sensitive as tissue blotting for detection of this virus. Since the virus is phloem limited, local concentration on tissue blots at the vascular tissue may provide a concentration of virus high enough for detection that is not available with homogenized tissue used in ELISA. Alternatively, the virus particles are degraded during binding to the membrane such that some of the protein is conformationally similar to subunits and recognized by the antibodies which were made to expressed protein rather than intact virus. This seems a less likely explanation, since a direct coating of virus onto ELISA plates did not result in a differentiation between infected and healthy tissue samples.

The effects of the pallidosis disease, now associated with SPaV and BPYV, on yield and vigor of strawberry plants is not devastating, although it has been shown in greenhouse studies using Fragaria $\times$ ananassa cv. Northwest strawberry that pallidosis reduced runnering and root mass (3). Our future plans include study of the effects of the disease on several other cultivars of strawberry plants and of the synergistic effects when it is present in complexes with aphid-borne strawberry viruses. We hope to obtain the complete sequence of $\mathrm{SPaV}$, while studies are un-

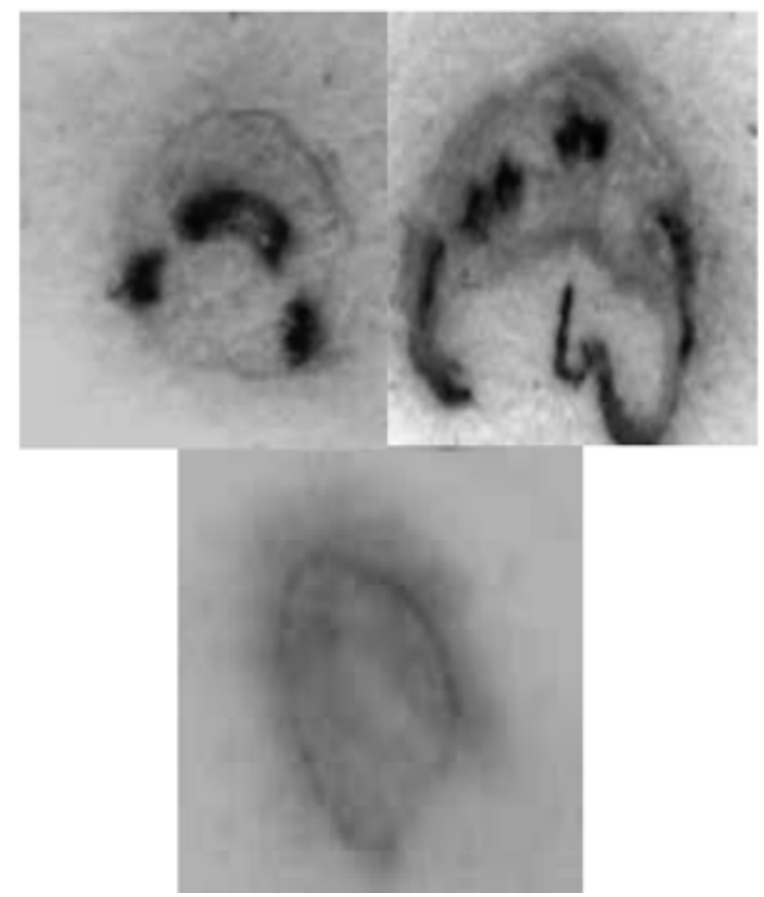

Fig. 4. Tissue blot immunoassay of petioles from pallidosis-infected (top) and healthy strawberry (bottom) showing intense precipitation in the vascular tissue of the infected plants (top).

derway to identify a vector of $\mathrm{SPaV}$ among the whitefly species that transmit criniviruses. Seed and/or pollen transmission of pallidosis has been suggested and will be examined in the future.

\section{ACKNOWLEDGMENTS}

We thank Kate Salazar for the grafting assays perform on the material from Maryland. We also thank the North American Strawberry Growers' Association and USDA for funding the project.

\section{LITERATURE CITED}

1. Chakrabarti, R., and Schutt, C. E. 2001. The enhancement of PCR amplification by low molecular weight amides. Nucleic Acid Res. 29:2377-2381.

2. Converse, R. H., and Martin, R. R. 1990. ELISA methods for plant viruses. Pages 179196 in: Serological Methods for Detection and Identification of Viral and Bacterial Plant Pathogens. R. O. Hampton, E. Ball, and S. De Boer, eds. American Phytopathological Society, St. Paul, MN.

3. Converse, R. H., and Volk, E. 1990. Some effects of pallidosis disease on strawberry growth under greenhouse conditions. Plant Dis. 74:814-816.

4. Craig, D. L. 1981. Strawberry cultivar reaction to pallidosis disease. Can. Plant Dis. Surv. 61:41-42

5. Frazier, N. W. 1974. Detection of grafttransmissible diseases in strawberry by a modified leaf grafting technique. Plant Dis. Rep. 58:203-207.

6. Frazier, N. W., and Stubbs, L. L. 1969. Pallidosis - A new virus disease of strawberry. Plant Dis. Rep. 53:524-526.

7. Fulton, J. P. 1987. Strawberry pallidosis. Pages 55-56 in: Virus Diseases of Small Fruit. R. H. Converse, ed. U.S. Dep. Agric. Agric. Res. Serv. Agric. Handb. 631.

8. Fulton, J. P., and Moore, B. J. 1982. Strawberry virus dissemination in Arkansas. Plant Dis. 66:847-848.

9. Henriques, M., and Schlegel, D. E. 1975 Studies on the nature of the strawberry pallidosis disease. (Abstr.) Proc. Am. Phytopathol. Soc. $2: 114$.

10. Hokanson, S., Martin, R. R., Heflebower, R. F., Jr., Rouse, R., and Maas, J. 2000. Survey of strawberry viruses occurring in commercial plantings in the state of Maryland, USA. Adv. Strawberry Res. 18:25-32.

11. Hughes, D. W., and Galau, G. 1988. Preparation of RNA from cotton leaves and pollen. Plant Mol. Biol. Rep. 6:253-257.

12. Jelkmann, W., Martin, R. R., and Maiss, E. 1989. Cloning of four plant viruses from small quantities of double-stranded RNA. Phytopathology 79:1250-1253.

13. Karasev, A. V. 2000. Genetic diversity and evolution of closteroviruses. Annu. Rev. Phytopathol. 38:293-324.

14. Klaassen, V. A., Boeshore, M. L., Koonin, E. V., Tian, T., and Falk, B. W. 1995. Genome structure and phylogenetic analysis of lettuce infectious yellows virus, a whiteflytransmitted, bipartite closterovirus. Virology 208:99-110

15. Little, A., Fazeli, C. F., and Rezaian, M. A. 2001. Hypervariable genes in Grapevine leafroll associated virus 1. Virus Res. 80:109116.

16. Mullin, R. H., Frazier, N. W., and Schlegel, D. E. 1975. Meristem culture of Fragaria chiloensis infected with strawberry pallidosis. Plant Dis. Rep. 59:268.

17. Sambook, J., Fritsch, E. F., and Maniatis, T. 1989. Molecular Cloning: A Laboratory Manual. Cold Spring Harbor Laboratory, Cold Spring Harbor, NY.

18. Tzanetakis, I.E. 1998. Comparative study of 
immunological methods for the detection of cucumber mosaic virus. Honors thesis. Agricultural University of Athens, pages 68-70 (in Greek).

19. Tzanetakis I. E., Wintermantel, W. M., and Martin, R. R. 2003. First report of Beet pseudo yellows virus in strawberry in the United States: A second crinivirus able to cause pallidosis disease. Plant Dis. 87:1398.

20. Wisler, G. C., Duffus, J. E., Liu, H.-Y., and Li, R. H. 1998. Ecology and epidemiology of whitefly-transmitted closteroviruses. Plant
Dis. 82:270-280.

21. Yoshikawa, N., and Converse, R. H. 1990 Strawberry pallidosis disease: Distinctive dsRNA species associated with latent infections in indicators and in diseased strawberry cultivars. Phytopathology 80:543-548. 